mentation; but to the historical eye no proof was needed of this fact. Hence the most important part of the first report was the evidence that soaking in a bicarbonate solution may retard deterioration by increasing the alkalinity, if such an over-simplified phrase can be employed for describing the specialized chemical formulations. (See the review of the first report by H. H. Fussler in CRL, XXI (1960), 417-19 p.)

The hope of most librarians, however, is that books should hereafter be printed on a non-deteriorating paper, since we now know the problem. To this hope Mr. Barrow and his staff have addressed themselves for two years. Unless a completely new substance like soybeans or a petroleum-based plastic should become technologically feasible as the raw material for paper, the work must be based on wood-pulp. The result must be suitably opaque, adaptable to different thicknesses and finishes, able to take printer's ink (unless new developments make letter-press printing itself obsolete), and commercially competitive with the many existing grades of acid sulphite paper; the wood-pulp itself and the sizing must blend to produce the desired result. Many if not all researchminded paper-makers have been concerned with the problem. With the co-operation of the manufacturers, Mr. Barrow has been able to specify commercially feasible alkaline-sized papers, using blends of wood-pulp prepared by the sulphite, sulphate, and soda processes, papers that can be priced competitively, hard-finished papers that ink adequately (or better than adequately) in letter-press and offset printing. The reports are printed on three of these papers, similar but not identical in specifications; to one of them the manufacturer has assigned the trade-name "Permalife." Save for a slightly mottled effect, not a serious blemish and probably susceptible to improvement, these papers are qualitatively equal to, or better than, most good papers now in use, in addition to their strength and resistance to deterioration.

The problem is not yet entirely mastered. Continued efforts by librarians and others will be needed to encourage manufacturers to continue experimenting, to produce permanent and attractive papers within several price ranges suitable for various uses. $\mathrm{Mr}$. Barrow's studies have pointed to one but not the only such product; the book trade and paper-technologists can work consistently towards the development of such papers. ALA was instructed by the conference last September to take the lead in guiding public opinion to encourage continued effort.A. T. Hazen, School of Library Service, Columbia University.

\section{A Second Edition}

Library Administration. By S. R. Ranganathan. (Ranganathan Series in Library Science, 3). New York: Asia Publishing House [1960, c. 1959]. 674p.

This volume traces its origin to the London School of Librarianship and to the lectures on "Library Routine" given there in 1924 by C. R. Sanderson. Mr. Ranganathan's experience was followed by observation of daily operations in more than a hundred libraries in the United Kingdom, by years of responsibility in the administration of the Madras University Library, and by thirty years of teaching library science. The first edition appeared in 1935 and "each chapter was tested by actual application in the dayto-day work."

"The book contained a forest of details ... enjoyed an unusually good reception" and went out-of-print in two years. Its republication has been deferred from time to time to permit the appearance of several volumes on the classification of books, a field in which the author has made a distinct contribution. However, substantial library subsidies from the government in India have recently emphasized the man-power shortage in librarianship and have lent urgency to the rewriting and republication of this book on library administration as a daily desk guide to management.

Chief among the changes incorporated in this second edition are (1) the staff formula to determine the strength of staff; (2) the prescription of routine on book orders; (3) simplification of the three-card system in the administration of periodicals; (4) changing the book card to a pocketed form and the reader's ticket into a non-pocketed plain card; and (5) the introduction of the conscience box.

As the author says "this is not a book to be read through ... It is, on the contrary, a 
most prosaic manual full of details .. . [for] the work table of one who has to carry on the administration of a library from day to day ..." This is not a book on theory. It "does not attempt either to discuss or even to state what the outlook of libraries should be." Despite this declaration by the author, Part I is called Theory of Administration and is divided into chapters dealing with planning, job analysis, routine, elimination of waste, correlation, time scheme, forms and registers, correspondence, files, and records; Part II, Distinctive Library Functions, deals with book selection, book orders, periodicals, concessions, circulation, reference, and maintenance; and Part III with General Office Functions. The latter heading includes committees, staff, and council, publicity, finance, accounts, and records, binding, building and equipment, printing, stores, and statistics, the librarian and the library profession.

This is a massive volume of 675 pages. The paragraphs throughout are short. Paragraph headings are set in a variety of typefaces as clear evidence of the outline and to each is prefixed a mnemonic faceted notation from the author's colon classification. The language is English, but much of the context will be foreign to American readers. Consider, for example, the Conscience Box:

Near the entrance wicket-gate, there should be a Conscience Box-a locked box with a small slit in its lid as the one in a temple, to collect offerings. Into this box the members delaying the return of books beyond the due date may drop their overdue charges. It should have glass sides. After practising the Victoria method of formally collecting the overdue charges with formal notice, issue of formal receipt, and maintenance of separate accounts, libraries have learnt that:

1. the game is not worth the candle, and

2. a splendid opportunity for the development of civic conscience is thereby being lost.

The Conscience Box Method is now adopted even for the collection of bus- fares in America. Our libraries should straightaway begin with trust in this manner. Trust will beget trust.--p. 275.

By its very nature as a collection of procedures and processes this book was compiled by many different hands, but all in all it is pure Ranganathan. There is, for example, a brief bibliography consisting of fifty-seven items, forty-three of which are citations to Ranganathan's own writings. The other works cited typically include Karston's Charts and Graphs (1925); McColvin's Library Extension Work (1927); McCord's Textbook of Filing; Cannon's Publicity for Small Libraries; Cockerell's Some Notes on BookBuying (all three 1929); Wyer's Reference Work (1930); and Headicar's Manual of Library Organization (1935).

The bibliography appears not to have been revised, nor indeed any other writings on this subject looked at since the publication of the first edition. Nowhere is there any mention of the basic contributions to library administration made by L. R. Wilson, E. W. McDiarmid, M. F. Tauber, or Guy Lyle, nor is there any mention of the wealth of supplementary material to be found in the many library periodicals published in English and in the languages of western Europe, such as Libri, The Library Quarterly, CRL, Library Resources \& Technical Services, Library Journal, The ALA Bulletin, the $\mathrm{Li}$ brary Association Record, and so on. One more conspicuous omission must be mentioned here. In the author's words "neither the size of libraries, nor the magnitude of their daily turnover, nor the cost of manpower in India, would justify or demand the introduction of photography and other mechanical and electronic aids in library routine."

This reviewer has long wondered how this one man could, as the book's jacket says, be the author of fifty books on library science, even during a thirty-year teaching career. Apparently the author lives and writes in a closely self-contained world of library practice.

This book will be of interest to research libraries and to library schools as a somewhat unique contribution to comparative librarianship. Beyond this its usefulness will have to be judged by the reader himelf.Frank A. Lundy, University of Nebraska. 